\title{
第 14 回(平成 15 年度)プラスチック成形加工学会論文賞選考報告
}

論文選考委員会*

審查委員長 黒 㟝 晏 夫

平成 15 年の本会学会誌「成形加工」に掲載された 37 編 の論文に対して，論文選考委員会において第 1 次，第 2 次 さらに最終選考委員会での慎重なる審査を経て本年度は下 表の 2 編が論文賞に選考された.

\section{論文の選考理由：}

「ポリアニリンの組成比を傾斜化したエンプラの自己組 織化的成形とその導電性」の論文は，導電性ポリマーがプ ラスチックマトリクス中で表面部分に多く存在するような 傾斜型あるいはステップ型構造を作ることで高価な導電性 ポリマーの添加量を最小限に抑え, しかも力学的物性の低 下を抑制しつつ高い電気物性を得る方法を検討している. また，そのプラスチック膜の製作を実証しており，学術的 および工業的に大いに評価されるものである.
「発泡成形における気泡成長の粘弾性解析」の論文は, 発泡成形樹脂の実用化が現在進められている中で，気泡成 長に及ぼす樹脂のレオロジー特性の影響を明らかにするた めに，粘弾性解析に高度な多重緩和モード PTT モデルを 用いる試みを行ったものである.

その検証は今後の課題であるが，手順を踏んだ高度な解 析予測方法は, 工学的に評価されるものである.

2 編の受賞論文は，世界的なレベルから見てももちろん 遜色のないものである。しかし，本会会員に対して，少し 欲張ったお願いをするとすれば，より多くの論文が投稿さ れることにより，優秀な論文がさらに増加し，本会の今後 の隆盛に貢献していただくことを期待している.

第 14 回（平成 15 年度）

プラスチック成形加工学会 論文賞

\begin{tabular}{|c|c|c|c|}
\hline 論文題目 & 受賞者 & 所 属 & 掲載 (巻·号) \\
\hline \multirow{4}{*}{$\begin{array}{l}\text { ポリアニリンの組成比を傾斜化したエンプラ } \\
\text { の自己組織化的成形とその導電性 }\end{array}$} & 亜輝 & 山形大学大学院 & \multirow{4}{*}{ 第 15 巻第 6 号 } \\
\hline & 折原 勝男 & 山形大学 & \\
\hline & 倉本 憲幸 & 山形大学 & \\
\hline & 野村 & 福島県ハイテクプラザ & \\
\hline \multirow{4}{*}{ 発泡成形における気泡成長の粘弾性解析 } & 大㭇 安彦 & 出光興産(株) & \multirow{4}{*}{ 第 15 巻第 9 号 } \\
\hline & 金井 俊孝 & 出光興産(株) & \\
\hline & 瀧 健太郎 & 京都大学大学院 & \\
\hline & 大嶋 正裕 & 京都大学大学院 & \\
\hline
\end{tabular}

\footnotetext{
* Kurosaki, Yasuo

電気通信大学 共同研究センター 東京都調布市調布ヶ 丘 1-5-1 2004.8.9 受理
} 